A Corrupt Medium: Stephen Burroughs and the Bridgehampton, New York, Library Author(s): Susanna Ashton

Source: Libraries \& Culture, Vol. 38, No. 2 (Spring, 2003), pp. 93-120

Published by: University of Texas Press

Stable URL: http://www.jstor.org/stable/25549087

Accessed: 01-11-2015 20:27 UTC

Your use of the JSTOR archive indicates your acceptance of the Terms \& Conditions of Use, available at http://www.jstor.org/page/ info/about/policies/terms.jsp

JSTOR is a not-for-profit service that helps scholars, researchers, and students discover, use, and build upon a wide range of content in a trusted digital archive. We use information technology and tools to increase productivity and facilitate new forms of scholarship. For more information about JSTOR, please contact support@jstor.org. 


\title{
A Corrupt Medium: Stephen Burroughs and the Bridgehampton, New York, Library
}

\author{
Susanna Ashton
}

In his eighteenth-century Memoirs, criminal Stephen Burroughs tells of his campaign to establish a library in Bridgehampton, New York. When the town elders discover the plan, they insist upon reviewing Burroughs's choices. Undercurrents of other debates spill over into what would otherwise merely be some quibbling over book selections. In a series of vividly recounted public meetings, Burroughs pits the local elders against himself and "the People." These book wars are clearly situated in ideological struggles regarding rationalism and the role of reading in general; but, more significantly, they are situated in a representational context that by its very genre-that of the rogue narrative-calls into question the role of individual interpretation and literary influence.

Minister Woolworth had not even read The Fool of Quality, so how could he possibly presume to criticize its style? Stephen Burroughs sneered: "So ignorant was this critic, that he did not know the books he undertook to condemn." With that damning point, Burroughs revealed his 1793 battle with the local Presbyterian minister over selecting books for a small-town library to be a battle over the power to define knowledge in the early republic. In his best-selling narrative, The Memoirs of Stephen Burroughs (1798), Burroughs tested the notion of responsible reading by framing his life story with discussions of reader accountability. Writing with the retrospective dignity of a middle-aged man looking back upon his misspent youth, he wryly described his dissolute life as the product of the pernicious influence of bad books. Yet this reasoning seems only a token nod to the generic conventions of his own criminal tale. Thus, when Burroughs chronicled his adventures in founding a community library, his analysis of how reading worked spoke to a complex understanding of how the interpretive imagination might be harnessed to create an ideal citizenry for a new nation. In place of a stable framework of values that are socially enforced by institutional agencies of culture (an educated elite, the 
ministry, a censored collection of books), Burroughs proposed the social purpose of encouraging the interpretation of values as a process of reading. He proposed a value for fictionality itself.

By looking at how he represents the debates and how his own memoirs continually address the problems of reading, interpretation, and community, we can see that Burroughs was questioning ideas about individual autonomy. He was, in many ways, a transitional figure in American literary and library history, a man who playfully argued for a nineteenth-, not an eighteenth-century, vision of reading as an active responsibility of the imagination.

In his Memoirs Burroughs represented the campaign to establish a library as something he did out of the goodness of his heart. As schoolmaster, the Burroughs narrator/hero was aware of the deficiencies of local scholarly resources in the small village of Bridgehampton, New York. He saw the town as "uniform, contracted, and uninformed" (271), so he obtained subscriptions from a number of townspeople to purchase an initial collection of books from New York City. When the town elders discovered the plan, they insisted upon reviewing Burroughs's choices. Book lists and requests were debated, titles were bandied about, and undercurrents of other debates over religion, power, and politics spilled over into what would otherwise have been merely some quibbling over book selections. In a series of vividly recounted public meetings, Burroughs pitted the local elders against "the People" as much as against himself. These book wars were clearly situated in historically ideological struggles regarding rationalism and the role of reading in general. Moreover, Burroughs recalled them in a genre-that of the rogue narrative-that itself questioned the role of books and reading. ${ }^{2}$

Burroughs's assumptions regarding his audience reflect a confidence in the reading public's support of his cause. His book choices suggest reason and sophistication. For much of his account he claimed that he selected books that he considered morally virtuous and intellectually stimulating. He defended his choices as innocent of guile, and he accused other people of selecting heretical and dangerous texts. His Memoirs, however, steadily operate to undermine any confidence one can have in Burroughs as a reliable protagonist. While he argued that bad books existed and should be avoided, his placement of such an argument in the curious venue of an unapologetic criminal memoir ultimately locates such an argument as firmly tongue in cheek. By displacing his own literary authority or at least problematizing it by continually referring to his own expertise as a liar, Burroughs suggested that readers must take on the perils and privileges of being responsible for their own reading. 


\section{Burroughs's Story}

The fundamental context for this story of a library is, of course, the book in which it appears. The Memoirs of Stephen Burroughs was first published in 1798 and quickly became one of the most wellknown rogue narratives of the nineteenth century, perhaps because it provided such a boisterous contrast to the many sober and spiritually oriented autobiographies of the period. ${ }^{3}$ Rogue narratives, which drew upon a British prose tradition of criminal narratives, dealt realistically and exuberantly with the adventures of thieves, vagabonds, and tricksters. In proper rogue-narrative style, the story of Burroughs's career began with various youthful escapades. He was born in 1765 , the son of a respected Presbyterian minister. A cheerful but mischievous boy, he stole watermelons, played pranks, and was known as a general menace to his Hanover, New Hampshire, community. At age fourteen he repeatedly ran away to join the Revolutionary army. His father pursued him and twice brought him home, but upon the third occasion Burroughs's commanding officer refused to release him. It wasn't until his father wrote Gen. George Washington, pleading for him to release his errant, underage son, that young Burroughs, already sick of the military life, was freed. He was subsequently enrolled in Dartmouth College, but, after two years of trouble making, he was expelled. He went to sea, but, after being convicted of stealing wine from his captain, he was briefly imprisoned in Massachusetts. Then, unable to settle down, Burroughs took off for what became a riotous journey across New England.

Relying upon a volume of his father's sermons, Burroughs gained notoriety by masquerading as an ordained Presbyterian minister for several months in Pelham, Massachusetts. As he moved from town to town and jail to jail, often only a step away from a lynch mob, his other exploits included passing counterfeit money, facing accusations of rape and seduction, accumulating unpaid debts, attempting to escape from various jails, and generally causing a public nuisance wherever he went. ${ }^{4}$ His escapades attracted widespread interest in local newspapers, simultaneously horrifying and fascinating readers. Burroughs later attributed many of his problems to exaggerated newspaper stories, which, he contended, unmercifully hounded and maligned him, thus ruining his reputation.

In 1788 he resolved to settle down and lead a quiet life. He married his cousin Sally Davis and obtained a position as schoolmaster in Charlton, Massachusetts. Nevertheless, all did not go smoothly in his life. He was jailed in Worcester, Massachusetts, for amorous involvements with various women, two of whom were his students, 
but he managed to escape from jail and move to Shelter Island, New York, where he again worked as a schoolmaster. After several months there, he heard of a better-paid position in nearby Bridgehampton, New York, a village located on the south shore of Long Island. In 1790 or 1791 he moved to Bridgehampton and took over the school. It looked as if his life had finally calmed down.

Founded in 1756, the town of Bridgehampton was part of a tight network of communities on the southern shore of Long Island. Directly south of Shelter Island and just to the west of Sag Harbor, Bridgehampton served the whaling and fishing industry as well as small farms spread across the island. Although there are no specific population records for Bridgehampton at this time, a sense of Bridgehampton's size can be inferred from the school enrollment: Burroughs stated that he had thirty pupils in his school.

With a number of small mills, a silversmith, a tavern, a wheelwright, a whaling station, a two-chimney schoolhouse, and a church, Bridgehampton was a small but thriving community. For Burroughs, relocating to Bridgehampton was a considerable step up in his quality of life. Not only did the Bridgehampton school district offer him more money than the tiny Shelter Island community had, but the slightly larger community also offered him what he hoped would be a more congenial society. His wife and children joined him, and he admitted his past indiscretions to the local elders. The community, in general, accepted him. All seemed well, until Burroughs noticed that "the people on this island were very illiterate. . . . They were almost entirely destitute of books of any kind, except schoolbooks and Bibles; hence, those who had a taste for reading, had not the opportunity" (279). With civic-minded magnanimity, Burroughs proposed the formation of a library.

\section{The Events}

Burroughs's relentlessly self-serving account describes the chain of events that led to the library controversy. He proposed a library to Minister Woolworth and was told that previous attempts at forming a library had failed. Undeterred, Burroughs forged ahead and collected money from various townspeople. The townspeople decided that Burroughs and four of the town elders, including Minister Woolworth and Judge Hulburt, would select the books. Woolworth presented a list of suggestions that horrified Burroughs because "his catalogue consisted wholly of books upon the subject of ethics; and did not contain a single history, or anything of the kind" (285). "To remain a silent spectator would be at once renouncing every claim 
to integrity," Burroughs protested, "inasmuch as I had promised the proprietors positively, that histories, and books of information on secular subjects, should give the leading cast to the complexion of the library" (283). Thus impelled to object, Burroughs argued for other titles.

When Burroughs suggested British novelist Henry Brooke's Writings, Woolworth objected. Woolworth complained that "no one can understand it, he writes upon such subjects, and in such an obscure manner; and all Burroughs's books are of the same cast" (286). Burroughs quickly asked who in the audience had read The Fool of Quality and thought it clearly written. After many members raised their hands, Burroughs announced triumphantly that the same man who had written The Fool of Quality, Henry Brooke, had also written Brooke's Writings! By publicly embarrassing Woolworth, Burroughs raised the debates to a more personal level, and the negotiations became increasingly bitter. Woolworth then persuaded the townspeople to vote for the list he had compiled, and, in response, Burroughs's faction decided to set up a separate library.

Despite wanting a separate library, the Burroughs faction nonetheless suggested to Woolworth that both factions order books collectively to save money on shipping and obtain bulk purchase discounts. While initially intrigued, Woolworth changed his mind about the dual library plan. "It was," he said, "departing from the dignity of their character to form a coalition with malecontents [sic]" (291). Woolworth insisted that all the townspeople deliver their funds back into his hands so that he could take control of ordering. The two factions negotiated a compromise, and the town decided that one library was, after all, in their best interests. Burroughs's original book selections were incorporated into the general order, and, as Burroughs put it, "[t]he books were sent for, and matters seemed to subside into a sullen calm" (292).

The final development in the library debates occurred, however, when Judge Hulburt decided that he was pressed for cash and offered to sell some books from his own private collection to the library. Seeing his chance for revenge, as Judge Hulburt had previously sided with Woolworth in objecting to Burroughs's books, Burroughs complained when the library committee agreed to purchase The History of Charles Wentworth from the judge. The volumes of this book, gleefully argued Burroughs, contain "a deistic treatise . . . as severe and ingenious as any extant" (293).

Defending his friend Hulburt, Woolworth argued that The History of Charles Wentworth was, for the most part, a good book. Woolworth claimed that "he had no idea of its being attended with fatal consequences, 
and had it not been for Burroughs, who is ever fond of making mischief, you would not have known that the book contained anything bad in it" (294). Several townspeople at the meeting argued that all of the offending passages should be read aloud, a suggestion that Woolworth and Hulburt rejected. There was then a general vote whether or not to exclude the book from the library, and the townspeople decided to keep it in the collection. Burroughs reasoned that this was because now everyone wanted to read this potentially dangerous novel.

Although the library issue was resolved (with the collection eventually serving the community for twenty years or so), the animosity between Burroughs and the other leaders of the community became so intense that when he was finally sued by one of his debtors, no one would help him, and he abandoned his pregnant wife and small children to the mercies of the community.

Burroughs went on to have several other escapades in the southern states and Canada, mostly involving land schemes and counterfeiting. It was in Canada that he wrote his memoirs, completing volume 1 in 1798 and volume 2, which contains his lengthy account of the Bridgehampton episode, in 1804. He died in 1840 at the age of seventy-five, but despite a long and raucous life, his stint in Bridgehampton was one of the most traumatic and influential events in his life, as demonstrated by the disproportionately long section of his memoirs devoted to it. While the popularity of his memoirs most likely stemmed from the notoriety derived from his counterfeiting schemes, his arrests for rape, his impersonation of a minister, and his escape from the Worcester jail, the conflicts he had in Bridgehampton (the center of which was the library debates) occupy approximately 75 percent of the second volume of his first edition. They represent the least glamorous and certainly the least action packed section of The Memoirs. While his previous adventures were those of a self-justifying rapscallion who moved on literally and figuratively every time there was trouble, the Bridgehampton experience is the only one in which he stays still long enough to truly paint the portrait of a community and his own relationship to it. Clearly, Burroughs presented himself and the debates over reading as central to understanding all of his previous escapades. His detailed analysis of the book debates as part of an attempt to involve his own audience of readers, to help them value the suppleness and individual interpretative authority that had shaped his own life. By focusing so intensely upon the library debates, Burroughs gave his readers a framework in which to place his own peripatetic shape shifting into the context of readerly self-determination. His suppleness could only be understood by supple reading. 


\section{Burroughs's Bridgehampton Library}

While the story of the Bridgehampton Library is remarkable for its detail and because the account is so powerfully recounted in a complex and influential literary text, the library itself was not particularly remarkable. Indeed, the Bridgehampton Library was a rather typical institution, arising from local interests in culture and funded by the individuals of the town rather than by a governmental ordinance ${ }^{6}$ Records indicate that the average social library before 1800 consisted only of approximately one hundred volumes on general subjects and included fewer than fifty members, which would describe precisely what we know about the initial collection and membership of the Bridgehampton Library. ${ }^{7}$ As William Gilmore argues, the late eighteenth and early nineteenth centuries marked the "first age of mass literacy" in the United States. As modern commerce developed, a growing network of communication and information that fueled what Gilmore terms "new cultural forms" accompanied it. ${ }^{8}$ These forms varied tremendously according to region, but one "form" that emerged was an increasing valuation of community libraries and the opportunities they offered. The story of the Bridgehampton Library provides an unprecedented insight into the issues surrounding the formation of many similar libraries during this period.

The spectacular growth of libraries in the United States following the American Revolution was a result of several factors. The Revolution itself had spawned an interest in current affairs and the cultivation of more extensive reading. New standards of citizenship became increasingly tied to the ability to converse intelligently about issues and reading material beyond theological or devotional works. ${ }^{9}$

While Benjamin Franklin's Philadelphia library was founded in 1731, and other large communities such as Charleston, New York, Newport, and Providence quickly followed suit, it wasn't until the 1760s that the library movement truly took off. It is difficult to determine whether this movement was simply an attempt of an increasingly settled and affluent nation to accumulate cultural capital or whether it was part of a growing fascination with new ways of valuing individual authority. (As I discuss later, the disparity of book topics and book titles in early American libraries makes it difficult to draw conclusions on this topic.) Nevertheless, as communities became more affluent, the growth of libraries increased. Many of these were circulating libraries, open to the public for a user fee. Most often, however, the libraries of the $1780 \mathrm{~s}$ and 1790s were what became known as "social" libraries, founded on an essentially corporate model. These libraries operated on a "per 
share" basis in which people pooled their funds to buy books for the collective use of the contributors. Between 1771 and 1780, 22 social libraries were established in the United States. Between 1791 and 1800, 226 were founded..$^{10}$ The Bridgehampton Library was founded in the midst of a significant cultural movement.

Social libraries, such as the one in Bridgehampton, were, as historian Jesse Shera puts it, "the libraries of a group of like-minded individuals." 11 In order for a social library to function successfully, its members needed to construct, however difficult that might be, a shared concept of the values they wished to be represented in their book choices. Unlike a circulating library, which might service individuals only interested in a one-time use, the premise of the social library as a collectively managed, joint-stock operation was significant inasmuch as social libraries ran into problems with establishing collections that appealed to all their members. Circulating libraries, with their varying clientele, were, more strictly, commercial ventures, answerable to market whims. Social libraries tried to consolidate values through a selection of books ordered by an elected committee. The committee, more often than not, was made up of the members with the largest shares in the corporation; hence the values of the most affluent members were disproportionately represented.

The rationales for establishing a social library varied, but if newspaper editorials of the period are indicators, the formation of social libraries was generally seen as improving both individual communities and the republic as a whole. As the New-York Magazine or Literary Repository of 1790 announced: "Of all forms of civil government, the republic depends most on an enlightened state of society, and this, among many other, is a strong proof of its superior excellence, that its very excellence is intimately connected with the mental improvements of its citizens." 12 Other editorials commented on the ability of social libraries to bind together the community and create a situation that would advance knowledge. The Time Piece of 1798 states:

Books may be much better preferred in this way, than if they belonged to individuals, and there is an advantage in the social intercourse of persons who have read the same books. ...

From this mutual intercourse, another advantage may arise; for the persons who are thus associated may not only acquire, but originate knowledge. ${ }^{13}$

By reorganizing social institutions, these new citizens of the republic saw themselves as displacing the traditional hierarchies of intellectual authority. The new libraries would give people the 
authority to originate knowledge rather than rely upon the knowledge interpreted for them by the college educated or by a clerical elite. ${ }^{14}$ Indeed, the attitude toward libraries in the late eighteenth century was so uniformly positive that by 1798 the New-York Magazine observed, "The advantage resulting to a community at large ... is too apparent and too well understood in this quarter of the world, to need any comment." 15

The rapid spread of various kinds of libraries did not, however, mean that these libraries were easily established. New London, Connecticut, a community far larger than Bridgehampton located right across Long Island Sound, only obtained its first circulating library in $1793 .{ }^{16}$ By one count there were only 157 libraries in the United States in 1790 , but 131 of them were in the Northeast, with a large percentage of those in New York State. ${ }^{17}$ For tiny Bridgehampton to gain a library of any kind in 1793 would have been a momentous event for that small community but not perhaps shocking to the increasingly cosmopolitan population of Long Island.

Once founded, social libraries tended not to be long-lived. As Shera notes, "Relatively few survived their founders." ${ }^{18}$ Despite the increasingly formal standards of incorporation (in 1796, for example, the New York State legislature passed laws concerning the management of incorporated social libraries) and their often standardized collections, the imprint of individual personalities upon these institutions superceded the communal nature or collective legacy that the corporate model might suggest. ${ }^{19}$ The Bridgehampton Library outlasted Burroughs's departure from the town, yet it is worth noting that residents of the town referred to it as the "Burroughs Library" into the late nineteenth century (see the appendix). ${ }^{20}$

\section{The Collection}

The limitations of understanding social libraries as seamlessly corporate rather than profoundly partisan or individual projects is apparent when one observes that social libraries of the period frequently disintegrated because of disputes regarding their book collections. ${ }^{21}$ In order to avoid such conflicts, many social libraries developed bylaws and clauses stipulating, as one Vermont library put it, that "all religious and sectarian books are forever excluded." 22 Similarly, Burroughs anticipated such problems: "I carefully avoided, from the beginning, offering any books of the sectarian kind, or that would have a tendency to lead the readers into religious disputes" (287).

Burroughs's caution in avoiding sectarian books was well founded. The selection of books could determine the success or failure of the 
enterprise. As Burroughs discovered, Minister Woolworth's earlier attempt to establish a library had failed because his fees were too high (forty shillings a person) and because, as one villager explained, nobody trusted him to buy appropriate books. Burroughs quoted his village informant as saying: "People are afraid they shall not be gratified in such books as they want so long as he [Woolworth] has the lead of the business. They generally expect the library will consist of books in divinity, and dry metaphysical writings; whereas, should they be assured that histories and books of information would be procured, I have no doubt they might be prevailed upon to raise money" (280). Burroughs's project, therefore, was undertaken in the context of an ideological tension already present in the town. $\mathrm{He}$ threw himself into a situation that had already defined its factions: Woolworth and his cronies versus the "common man." Burroughs read the situation to his own benefit and positioned himself on the side of the common man, who would eschew dry theological writings and instead prefer factual and self-improvement books. This may not be in accordance with what the situation actually was (if book sales or the records of circulating libraries can be used as any indicator, fiction was really what eighteenth-century Americans wanted), but this was how Burroughs depicted it. ${ }^{23}$

Burroughs identified the troublesome factions in the library committee by marking out the kinds of books they respectively desired. Deacon Hedges brought forward the title of a number of religious pamphlets: "Essays on the Divine Authority for Infant Baptism," "Terms of Church Communion," "The Careful Watchman," "Age of Grace." ${ }^{24}$ Cook, who Burroughs identifies as the leader of a small religious group, the Separates, requested titles such as the Rights of Conscience, Defense of Separates, and Fox's History of Martyrs. ${ }^{25}$ Woolworth, in rebuttal, listed Edwards against Chauncey, History of Redemption, and Jenning's Views-all works of ethics and conservative religious doctrine. ${ }^{26}$ Doctor Rose, a villager characterized by Burroughs as "a libertine in practice" (270), was the only person to request anything that we might term "light reading" today. He called for Gay's Fables (an immensely popular collection of political satire), Pleasing Companion (possibly a poetry anthology), and Turkish Spy (a well-known collection of pseudoforeign letters written in the late seventeenth century and later updated by Defoe). Burroughs himself suggested Hume's History, Voltaire's Histories, Rollin's Ancient History, and Plutarch's Lives. ${ }^{27}$

Despite cleavages among groups, Burroughs saw two basic factions: those people who were happy with Woolworth's list and those who were not. When Burroughs and his faction then proposed to 
create two entirely separate libraries, Woolworth complained that two libraries would be divisive and destructive to the community. As Burroughs reported, Woolworth invoked a war metaphor that could not have been missed by people only one generation away from the American Revolution. "While we are pursuing the object of two libraries I fear we shall fail in both; being divided, we shall in our operations militate against each other, and finally both come to the ground," argued Minister Woolworth (290-91). Burroughs and his faction countered by invoking natural rights: "Every idea we entertained on the subject was to purchase such books with our money as we wished for. This was a right which we inherited from nature, and which we did not intend to give up" (291). This understanding of rights as predicated upon the ability to purchase property and participate in the economy as they saw fit was yet another aspect of the ideological battle fought under the auspices of a library dispute. No self-appointed cultural gatekeepers were to infringe upon the "natural" right of citizens to dispose of their property as they saw fit.

Burroughs aligned himself with the unhappy camp for reasons that went beyond his self-professed championing of the common folk. As the story of the library progressed, it becomes more clear what Burroughs really saw as "at stake" in these disputes. His self-proclaimed position as an oppressed and victimized member of society aligned him with the population he championed. Yet this position was compromised by his condescending attitude toward the villagers ("the people were very illiterate, making but a small calculation for information, further than the narrow circle of their own business extended" [279]). How well could this antielitist, this champion of individualism really identify with them? This seeming contradiction makes a certain kind of sense, though, when considered alongside his essential pose in The Memoirs: that of an identity in flux. Burroughs's contradictions highlighted his valuation of suppleness. This was manifest both in his personal life and in his arguments about books and interpretive reading strategies. ${ }^{28}$

\section{The Nature of Evidence}

Is a rogue narrative a problematic source document for historical information, or is the text of a rogue narrative primarily a hermeneutical field that, however historicized, speaks only to premises of representations and systems of meaning? When a rogue narrative such as Burroughs's addresses questions over reading, libraries, and the definition of a bad book, the slippery questions over how to understand his text, much less the cultural agency of the institutions he 
invokes, become especially troubling. As one reader of Burroughs's narrative said to me, "But how can you believe anything he said? He's an unreliable narrator!" The indisputable truth behind my colleague's observation demonstrates precisely why The Memoirs of Stephen Burroughs is perfectly situated to teach us about reading, libraries, interpretation, and the very concept of cultural agency. For the rhetorical strategies of a literary text can tell us about the nature of authority, credibility, and liability that were at stake in the historical experience of reading in general and of the cultural agencies of libraries in particular.

In some ways, my arguments invoke textual materialism and artifactual evidence. Much of what Burroughs said about the debates, the town, and the library can be traced. Prison records, school records, legal proceedings, and witness accounts support the bulk of his narrative. More significantly, four volumes mentioned by Burroughs still sit on the shelves of the Hampton Library in Bridgehampton today and offer much material evidence about readerly interests of the period. These physical texts and the stories they tell certainly remind us that even the most suspect artifact transmits a tangible assertion of cultural conditions.

On the other hand, the story of Burroughs and the Bridgehampton Library illustrates also how we need to invoke evidence available to us through the discursive and disembodied imaginative text as much as the material one. For Burroughs's extreme slipperiness reminds us how genre (in this case, a criminal narrative) is a historical idea and how the deliberate ambiguity of his position actually underscores the complexity of all materialist evidence.

Indeed, I argue that The Memoirs's celebration of supple reading offers an opportunity to ask questions about the historical and cultural role of libraries. To understand how libraries and reading were culturally imagined, we need to understand that sifting unreliable accounts to find "truth" about their role is hardly an exhaustive or satisfying exploration of the possibilities a text offers us. Instead, texts like Burroughs's memoirs remind us how much richer and fuller our understanding of reading can be when we use the unreliability itself to approach the necessarily historicized world of American libraries.

\section{Bad Books}

Burroughs admitted that his Memoirs lent itself to flexibility and interruption. He wrote: "When you become tired of reading, you will be under no necessity of holding the book in your hand from the feelings 
of delicacy, but can lay it by at leisure. This liberty you could not so conveniently take with a dull relater of a more dull narrative" (1). He described his narrative as one that celebrated individual interpretation. He wrote, "We are too apt to be governed by the opinion of others" (2). Certainly, with an eye to the marketplace, Burroughs would have wished The Memoirs to appeal to as many interpretations as possible. Contradiction, therefore, was not simply a thematic pose for an appropriately fluctuating identity. It also fit conceptually with his Memoirs as the commodity product it quickly became.

The ability to juggle contradictions rather than resolve them emerged as an issue in the library debates when the less-educated villagers were given an opportunity to assess their own abilities to distinguish between good and bad books. Burroughs initially pretended to go along with the terms of the debate. He denied having placed "bad books" in the library but did not deny the possibility that a "bad book" could exist. When, after the initial flurry of book debates settled down, and Judge Hulburt offered to further supplement the collection by selling a couple of his own books to the library, Burroughs saw his opportunity to manipulate the bad book premise to his own advantage. He accused Judge Hulburt of having himself placed a dangerous book in the library, and, with theatrical flair, Burroughs then gleefully waved the book in question before the assembled villagers. With ridiculously stylized language he wrote:

Aghast, in wild dismay, they started back with horror! . . . To see their library ... thus corrupted by the vilest heresy, and blackest poison, after they had taken such unwearied pains to obtain one, pure as nature's simple fount, or the gurgling rill rolling its lucid streams over the brightest pebbles, was a sight which made every feeling of holy wrath burn with fury against the unknown traitor. They were loud in their clamours to the librarian to know who was the author of this abominable deed. (293)

The obvious sarcasm here undermines the argument of believing books to be pure or impure. Most crucially, however, Burroughs pointed out that the dangerous quality of the unnamed volume needed to be judged by the villagers themselves. Burroughs declared:

He [Judge Hulburt] says you would never have known that the book had been a bad one if I had not told you!! He appears to be entirely willing that you should have bad books, to be cheated out of your money, to be wronged, imposed upon and abused, 
provided there is nobody wicked enough to tell you. . . . If your ignorance would be an antidote against the poison of such books put into the library by Judge Hulburt, why not the same reason in my favor? (294)

By asking the villagers if their "ignorance" would be an "antidote," he was not making an appealing argument. For who would wish to identify himself as ignorant and thus defend Burroughs? By posing such a defense, Burroughs acknowledged that the villagers had the ability to interpret books strategically on their own terms. He flattered them by offering them the very weapon with which to attack him (their own judgment), confident that they would refrain from doing so. When Burroughs asked, "[W]hy not the same reason in my favor," he effectively deconstructed the very premise of the argument. The reason he invoked was not ignorance as antidote; he appealed instead to rebellion against imposed cultural authority, a rebellion with which he presumed the audience of The Memoirs to be sympathetic.

The actual presence of a book that Burroughs himself identified as "bad" (however convenient this label may be for him) altered the tenor of the debate. For, as Burroughs's own rogue narrative attested, people were more interested in "bad" narratives than in "good" ones. The book introduced by Judge Hulburt was Edward Bancroft's novel The History of Charles Wentworth. The townspeople heard the debates over The History of Charles Wentworth and, presumably to the annoyance of Woolworth and Hulburt, voted to purchase the book anyway. Burroughs explained: "The truth was this; there had been so much said respecting the book, that each individual was anxious to gratify his curiosity by seeing this phenomenon; and each one who had read it, was more afraid for others than for himself, therefore it was determined that the book should remain a member of the library, in order for each one to be gratified by the perusal" (296).

With this analysis, Burroughs's positioning of himself in the dispute becomes clear. He may have been somewhat tongue in cheek when he argued over the deistic dangers in The History of Charles Wentworth, but he participated willingly enough in the dignified dispute over which books would and would not be appropriate in a library. His position was not entirely ironic, despite highlighting the humor in everyone's desire to personally inspect the offending passages. To his mind, certain books could influence if not necessarily damage young people. Indeed, he coyly attributed his own criminal career in part to the irreparable damage to his character caused by overexposure to novels as a child. "Reading and dwelling so much 
on those romantic scenes, at that early period of life, when judgment was weak, was attended with very pernicious consequences in the operations of my after conduct" (4-5).

This position on the pernicious effect of "bad books" and particularly of fiction was consistent with the arguments he put forth on the problems of what he termed "bad books" in libraries. Burroughs's sly asides and often implausible rationalizations for his antisocial behavior (his rape conviction, for example) keep the reading audience aware of how his elaborately charming persona was crafted. Our criminal was almost too likeable to be true. Irony creates an awareness of artifice. The implausibility of books as the primary causes for his shady career reminds us of just how manipulated we are by our hero.

Yet the argument that romantic novels shaped his character was true in a variety of ways. Many of his longings for understanding and sympathy were couched in often-persuasive sentimental conventions. But more important, just as he argued that novels led him astray and created his disingenuous self, so too he made it clear that The Memoirs created a persona, that of the rogue hero. Despite the irony, Burroughs had a genuine allegiance to the idea of books as shapers of a counterfeit self, indeed, a literary persona. Just as he had placed counterfeit money into circulation, he placed his own counterfeit self into the hands of readers. And in both cases his esteem for the counterfeit self was such that he didn't really see either project as corrupt.

Burroughs was first persuaded to counterfeit money because, as his friend Lysander explained, "The only thing necessary to make a matter valuable, is to induce the world to deem it so" (83). Since money was merely a portable representation of property, as Lysander saw it, keeping a "due proportion between represented and real property" was a favor to society (84). To make sure that enough representations were in circulation, whether or not they had a base in reality, was not corrupting people's understanding of social systems; rather, it fed the desire for representations in general. Similarly, by reminding readers of the artifice behind his persona as rogue hero, Burroughs underscored the importance of keeping representations in circulation. Keeping people aware of representations forces interpretative and supple thought that in turn could create the only reality Burroughs valued.

Throughout The Memoirs Burroughs demonstrated that his perceptions of reading and interpreting differed from the systems he saw operating around him. Implicitly, of course, Burroughs described his escapades with the assumption that his real audience (the readers of The Memoirs) would recognize how reading and interpreting really should function. This stance on the power of interpretation demonstrates a 
consistent strategy in representing himself as the medium for what is often construed as "corrupt" or "bad" (such as when he passes counterfeit money) but that tends to do no harm and, more significantly, is not really worth controlling. ${ }^{29}$ After all, the townspeople had been interested in Judge Hulburt's "bad book." Thus it wouldn't be surprising for people to be interested in the lives of rogues and criminals, a fact to which Burroughs's successful Memoirs stood testament. The concern with keeping the library "pure" from deistic writings or bad books parallels a concern for keeping Bridgehampton pure from scoundrels, both concerns he thought unfounded.

For example, much of Burroughs's notoriety resulted from his impersonation of a minister. He defended himself on the grounds that his preaching did no harm, and the impersonation had not been done with the intent to "damage" other people (67). Indeed, he reasoned that no harm was done. This defense recognized that reading and interpretation are personal things, and, as Burroughs saw it, even a bad text can be made good with the correct audience. If he, as minister, was the "bad text," that badness didn't seem to rub off on his parishioners. And just in case anyone might accuse him of using a good book (the sermons he steals) and delivering good works in a bad manner, he reports that his sermons were received with no ill effects.

When Burroughs was caught using cribbed sermons, the locals decided that to prove his genuine ministerial ability he would have to deliver upon short notice a sermon about a random scriptural passage. He did so, and his impromptu sermon was well received, proving his point that interpretation is an act essentially divorced from any control one can wage over the medium. To further his case, Burroughs included his extemporaneous sermon in the text of The Memoirs. While he had been given an especially odd scriptural passage from which to assemble a sermon (Joshua 9:5: "And old shoes and clouted on their feet" [55]), he managed to put together a relatively coherent-albeit amusing-speech. By showing it to his broader audience, the readers of his Memoirs, he demonstrated that the medium does not necessarily warp the message, no matter how bizarre the message may have been.

The overarching concern for how he is a medium for corruption is epitomized by the medium in which he touts this argument: The Memoirs. For although The Memoirs of Stephen Burroughs was one of the best-selling books of the early nineteenth century, it would not have been included in the collections of libraries during that period. And it most certainly would not have been found in the Bridgehampton collection, if the comments by the local press were any indication. In December 1798, for example, the Long Island Herald noted the 
publication of Burroughs's Memoirs with the following observation: "Query-Would not a book with the following title be as popular as the moral memoirs of Burroughs? 'A History of the Devil, written by himself, and published at the request of many of his hearers. ${ }^{\prime 30}$

As Philip Gura argued, Burroughs "offers us another American story, having more in common with that represented by Melville's Israel Potter or Charles Brockden Brown's Carwin than by those like Franklin who found in America a well-paved avenue to financial and social success." ${ }^{11}$ Gura saw Burroughs's account as one that asserted the doubts of the citizenry about how the nation's laws were often interpreted. That Gura then aligns Burroughs's experience with two fictional life stories is therefore especially telling. For if The Memoirs were in some way intended to prove how the interpretation of dry legalities might often not do justice to the ever more flexible and true nature of justice and reality, the Melville and Brown comparisons are especially apt. For Burroughs, the interests of the common man were to combine practical knowledge with the freedom that fiction could provide. Fiction as genre may not have been openly debated, but underlying even the discussion over the improving texts was the question of just what free interpretation could be.

Once agreed upon, the Bridgehampton Library collection included novels such as Brooke's Fool of Quality, to which Minister Woolworth had originally objected..$^{32}$ But no rogue narratives made the list (unless one includes Franklin's Life, a book that one suspects was Burroughs's, not Woolworth's, contribution). This library omission may ultimately have served Burroughs's own bad book of memoirs well. By reading The Memoirs, the reader participates in an exclusive relationship with the author. Burroughs implied that not just anyone could be privileged enough, savvy enough, or open-minded enough to handle his work. The reader of The Memoirs could bask in the knowledge that he or she possessed the interpretive skills necessary to understand the complexities of Stephen Burroughs. Indeed, the reader could take on the devil as an equal.

Fiction, with its evils and its merits, was under debate throughout the late eighteenth and early nineteenth centuries. But, as library collections prove, fiction's advocates were winning. Even the most genteel social library, such as that proposed by the Harris catalog, would still include a fair amount of fiction, and, as many scholars have shown, circulation records attest that the fiction was disproportionately circulated. ${ }^{33}$ What is most surprising about the Bridgehampton Library battle is that the merits of fiction was not the issue under fire. After all, The Fool of Quality was not merely a popular sentimental novel; it was the single most frequently listed 
novel in American catalogs of books between 1750 and 1800 and would presumably exemplify the incursions fiction had made into the eighteenth-century American reading culture. ${ }^{34}$ This immensely popular book was irrefutably fiction, but, more interesting, it appealed to several different types of readers. As literary historians David Hall and Robert B. Winans have both argued, three large groupings really divide the way in which early Americans read: readers of religious and devotional material, readers of fiction, and readers of romances and fairy tales. The Fool of Quality, which was a loosely structured novel of sensibility, promoted an intensely religious outlook and yet did so through basic allegorical premises; it thus likely appealed to all three groupings of that time. Even Thomas Jefferson, who was not especially fond of fiction, recommended its inclusion in a model library collection. ${ }^{35}$ Therefore, when The Fool of Quality comes under attack, its very broad-based appeal lends an especial resonance to the debate. It is the nature of its fiction that is at issue, and as a tremendously successful book, questioning even the nature of its fiction is questioning the judgment of many different types of readers.

What actually occurred in the discussion of The Fool of Quality was not part of the stereotypical fiction debate. Woolworth and Burroughs debated the deistic contents of the book and the ability of readers to handle offending passages, yet neither Woolworth nor Burroughs chose to raise the issue of fiction itself. Although the majority of the book list they assembled was nonfiction, their avoidance of the fiction debates indicates some shared assumptions about how reading and interpretation were liable to work. Curiously, one of these assumptions seems to be that the quality of the writing was somehow key to considering whether the work was good or bad-an assumption that confuses the idea of books as somehow having a bad effect because of their ethical content. Burroughs's inclusion of The Fool of Quality discussion in his Memoirs is consistent with his broader constructions of truth. His own work, which would easily be prone to charges of falsehood or exaggeration, would be implicitly excused from such charges if fiction could somehow be extricated from complete moral depravity. His own dependence upon lies and falsehoods to operate in society (such as when he poses as a minister) indicates a valuation of fiction despite any protests he may have made to the contrary.

In her analysis of early-eighteenth-century criminal narratives and gallows literature, Kristen Boudreau argues that the appeals to public sympathy often found in these works could turn readers against the clerical and judicial institutions that originally created and controlled their publication. By strongly identifying with the criminal, the spectators of these executions and readers of their descriptions challenged 
the premises underlying the authority of the republic. ${ }^{36}$ Burroughs's own late-eighteenth-century narrative was a far more rhetorically complex work than most of the basic eighteenth-century gallows pamphlets, but Burroughs similarly relied upon exploiting the intimate relationship between reader and narrator. Burroughs's constant appeals to readers' sense of irony and justice indicate a faith that readers will identify with his own suffering even when recognizing the manipulative rhetoric in action. The intensity with which Burroughs campaigned for the people's library against the clerical/judicial choices underscores not merely his own anti-establishment sentiments but also his understanding that public sympathy could have very real consequences for him. Just before he had made his way to Long Island, Burroughs had been freed from a prison in Worcester, Massachusetts, by a sympathetic group of townspeople who were horrified at the harshness of his sentence. Despite being found guilty of assault with the attempt to rape, his personal charisma had made him many local friends. The sentence, which had included, among other things, 117 stripes to his back, three months in prison, two months in the pillory, and one hour on the gallows, was partly carried out, including, presumably, the public displays, during which he would have had ample opportunity to generate public sympathy. In the middle of the night, as Burroughs reported it, the prison door was opened, and a crowd of perhaps a thousand locals escorted him out of jail. Appeals to sympathy and fellow feeling were not, therefore, vague concepts for Burroughs. Logistical support as well as emotional sustenance were things from which he had previously profited. Hence, when he demonstrated a great trust in the reading public itself to decide what was and was not a bad book, Burroughs demonstrated a faith both in the public's good decisions and in the public's appreciation of his alleged respect for their opinions.

The issues of liability and self-determination at stake in debates over libraries here are thematized as issues of literary authority. His text, then, becomes an argument about a new manner of reading that he takes to be at issue with the library. The prominence of the library in his memoirs is, in fact, a defense of his credibility.

Burroughs's narrative promotes a model of reading that links the autonomy of individual identity to the taste we acquire for "representations." Readerly pleasure, in this model, cultivates an appreciation for instability and the agency of the reader to make judgments. What's at stake then in his literary act of self-invention is an argument about how subjects should be constituted in the new print economy of the early republic. Thus, does self-invention of corrupt rogues, not less than of readers, become the governing value of liberal individualism? 


\section{Notes}

Many thanks to Michelle Smith, Steve Jones, Amelia Borders, Ann Sandford, David Spector, Ken Carpenter, the staff at the Houghton Library at Harvard University, the Bridgehampton Historical Society, the Shelter Island Historical Society, Columbia University Libraries, Clemson University Library, the editorial staff at American Studies, the anonymous readers at Libraries $\mathbb{E}$ Culture, and the Hampton Library in Bridgehampton for assistance with the thinking, research, and computer support necessary to this essay.

1. Stephen Burroughs, The Memoirs of Stephen Burroughs (Boston: Dial Press, 1924; reprint, Boston: Northeastern University Press, 1988), 286. All further citations are from this edition and will be cited parenthetically. Henry Brooke's Fool of Quality, or, The History of Henry, Earl of Moreland was written from 1765 to 1770. The Reverend Aaron Woolworth (1763-1821) graduated from Yale in 1784 and was given an honorary degree from Princeton in 1809. He was appointed minister to the Presbyterian Church of Bridgehampton in 1787. For a portrait of Woolworth, see Nathaniel S. Prime, The History of Long Island, from Its First Settlement by Europeans to the Year 1845 with Special Reference to Its Ecclesiastical Concerns. In Two Parts (New York: Robert Carter, 1845), 1:201-4. See also Ebenezer Philips, Sermon Delivered at Bridge-Hampton, (L.I.) April 25, 1821, Occasioned by the Death of the Rev. Aaron Woolworth, D.D. Pastor of the Church in That Place, Who Departed This Life, April 2nd, 1821 (Jamaica, N.Y.: Henry C. Sleigh, 1821).

2. As Robert Darnton argues, the communications circuit of publishers, shippers, booksellers, libraries, readers, and authors needs to be understood as circular, because readers influence a text both before and after its production. After all, authors are readers, and their notions of generic expectations and even systems of representation take on their full significance only when associated with a sense of the full circuit operant in book history. See Robert Darnton, "What Is the History of Books," in Cathy Davidson, ed., Reading in America: Literature and Social History (Baltimore, Md.: Johns Hopkins University Press, 1989), 27-52.

3. The Memoirs of Stephen Burroughs was originally published in two volumes, the first in 1798 in his hometown of Hanover, New Hampshire, and the second in 1804 in Boston. The two-volume Memoirs was then issued together in Hanover in 1804. In 1809 an abridged version of the story, Sketch of the Life of the Notorious Stephen Burroughs Containing the Most Interesting Events of His Life, as Given by Himself, appeared in New York. Beginning in 1832, subsequent editions of The Memoirs were issued under the title Memoirs of the Notorious Stephen Burroughs and other similar titles. For a thorough discussion of the publication history, see Philip Gura's foreword to the 1988 Northeastern University Press edition of The Memoirs. One lively interpretation of Burroughs places his work in a picaresque tradition of the novel. See Christopher W. Jones, "Praying upon Truth: The Memoirs of Stephen Burroughs and the Picaresque," Early American Literature 30, no. 1 (1995): 32-50.

4. For an account of his imprisonment and the historical context of penal culture at that time, see Linda Kealey, "Punishment at Hard Labor: Stephen Burroughs and the Castle Island Prison, 1785-1798," New England Quarterly 57, no. 2 (1984): 249-54. For the story of one of Burroughs's accomplices, see Gwilym R. Roberts, "Elijah Remington, the Castleton Counterfeiter," Vermont History 34, no. 1 (1966): 66-69.

5. Judge Hulburt's name is spelled with some variation in older documents. Burroughs refers to Judge "Hurlbut," which is, according to the local histories, incorrect. I have corrected and standardized the spelling throughout this essay. 
6. The extant catalog of the Bridgehampton Library indicates that it was quite similar to other collections of the period. As indicated by Haynes McMullen, the most common form of social or per-share library before 1876 was what he terms "general in content." See "Subject Matter of the Collections," in Haynes McMullen, American Libraries before 1876 (Westport, Conn.: Greenwood Press, 2000), 147-53.

7. For tables calculating the distribution of volumes and membership, see Jesse H. Shera, Foundations of the Public Library: The Origins of the Public Library Movement in New England 1629-1855 (Chicago: Shoe String Press, 1965), 75, 77.

8. William J. Gilmore, Reading Becomes a Necessity of Life: Material and Cultural Life in Rural New England, 1780-1835 (Knoxville: University of Tennessee Press, 1989), 20-21.

9. For a good summary of these issues, see Richard D. Brown, "Afterword: From Cohesion to Competition," in William L. Joyce, David D. Hall, Richard D. Brown, and John B. Hench, eds., Printing and Society in Early America (Worcester, Mass.: American Antiquarian Society, 1983), 305.

10. For specific figures, see Shera, Foundations of the Public Library, 55, 69. A thorough case study of one such community's library is Harry Miller Lydenberg, "The Berkshire Republican Library at Stockbridge, 1794-1818," Proceedings of the American Antiquarian Society 50 (1940): 111-62. See especially his analysis of the growth of Massachusetts libraries in the late eighteenth century (141-43). Robert Gross argues that the social libraries of late eighteenth and early nineteenth centuries were part of a campaign to "remake Americans into a 'reading generation." See Robert A. Gross, "Reconstructing Early American Libraries: Concord, Massachusetts, 1795-1850," Proceedings of the American Antiquarian Society 97, no. 2 (1987): 331-451.

11. Shera, Foundations of the Public Library, 105.

12. "On the Utility of Public Libraries," New-York Magazine or Literary Repository 2 (1790): 307.

13. Time Piece 1 (January 1798): 13.

14. For further discussion of how print culture in early America was imagined as part of the democratization of the country, see David Jaffee, "The Village Enlightenment in New England, 1760-1820," William and Mary Quarterly 47 (July 1990): 327-46.

15. "On the Utility of Public Libraries," 307.

16. Elizabeth W. Stone, American Library Development 1600-1899 (New York: H. W. Wilson, 1977), 137.

17. See McMullen, American Libraries, 48, table 3.3.

18. Shera, Foundations of the Public Library, 72.

19. Ibid., 62.

20. The current library in Bridgehampton has been called the "Hampton Library" since its incorporation in 1877. I use "Bridgehampton Library" to refer to the original library of 1793 that eventually became known as the "Burroughs Library."

21. In one such instance, a library founded in 1793 in Pomfret, Connecticut, caused a local uproar because of its supposed emphasis upon theological works at the expense of a broader collection. In protest (just as in Bridgehampton), a competing junior library was organized. It was not until ten years later that differences were reconciled enough for the two Pomfret libraries to merge (Stone, American Library Development, 138).

22. Shera, Foundations of the Public Library, 104.

23. From 1778 to 1798 there was a 1,200 percent increase in the appearance of literature in the subject of American printed works. "[O]f course there was a 
population increase of 190 percent during this time and an overall rise in book production during this period of 400 percent, but nonetheless, there was a disproportional increase." See David Kaser, A Book for Sixpence: The Circulating Library in America (Pittsburgh, Pa.: Beta Phi Mu, 1980), 45. For an analysis of how circulating libraries came to be commonly associated with fiction reading, see Ross W. Beales and James N. Green, "Libraries and Their Users," in A History of the Book in America, vol. 1, The Colonial Book in the Atlantic World, ed. Hugh Amory and David C. Hall (Cambridge: Cambridge University Press, 2000), 399-404.

24. None of these titles appears on the extant library list. Whether the pamphlets might have been purchased and simply did not survive into the nineteenth century, which is when I suspect the list was compiled, is difficult to say. It seems more likely that only books were considered part of the core collection and that pamphlets of any sort were not purchased for the library.

25. Rights of Conscience was likely a version of John Leland's Rights of Conscience Inalienable, and Therefore Religious Opinions Not Cognizable by Law: or, The High-flying Church-man, Stript of His Legal Robe, Appears a Yaho (1791). I was unable to find a likely reference for Defense of Separates. Fox's History of Martyrs was most certainly a reference to John Foxe's Book of Martyrs (1563).

26. Edwards against Chauncey was doubtless a version of Jonathan Edwards's Salvation of All Men Strictly Examined: And the Endless Punishment of Those Who Die Impenitent: Argued and Defended against the Objections and Reasonings of the Late Rev. Doctor Chauncy, of Boston, which wasn't published until 1790. Woolworth's second title was a reference to Edwards's History of Redemption: On a Plan Entirely Original: Exhibiting the Gradual Discovery and Accomplishment of the Divine Purposes in the Salvation of Man; Including a Comprehensive View of Church History, and the Fulfilment of Scripture Prophecies. This text was based on a series of sermons from 1739 but was only first published in 1774 . Jenning's Views may be the same book that ended up on the extant list as Jennen's View and Jennen's Lectures (see the appendix). Woolworth was likely referring to the works of Soame Jenyns (1704-87), whose View of the Internal Evidence and Lectures were frequently reprinted in America during the 1780s and 1790s. Jenyns, an old opponent of the American Revolution, argued that illiteracy and ignorance were socially useful. Ignorance was "the only opiate capable" of letting the poor accept the horror of their lives (quoted in Brown, "Afterword," 304).

27. Plutarch's Lives was available in many translations from the original Greek throughout the United States in the eighteenth century. Charles Rollin (1661-1741) was the immensely popular and often reprinted author of The Ancient History of the Egyptians, Carthaginians, Assyrians, Babylonians, Medes and Persians, Macedonians and Grecians (1730). Voltaire's extensive writings on the history of England and Europe were variously collected in hundreds of editions throughout the eighteenth century. Voltaire's Histories could have been any of a hundred different compilations and collections. David Hume's History of England from the Invasion of Julius Caesar to the Revolution of 1688 (1754) was also likely one of the books Burroughs himself suggested. According to one local history of Bridgehampton, the entire scandal had begun when Stephen Burroughs introduced Constantin Volney's Meditations upon the Ruins of Empires into the library. This work, translated from the French by the American writer Joel Barlow, was never specifically mentioned by Burroughs. Nor does the catalog of the final library indicate that Volney's Ruins was ever purchased. Yet if Burroughs had mentioned this title, it is not unreasonable to suspect that the town elders would have been distressed. It is certainly possible that Burroughs avoided mentioning this title because it would have been even less well 
received than the Hume or the Voltaire. Volney's Ruins was a key Enlightenment text, featuring a series of reflections upon the relationship between ancient and future civilizations and concluding that, guided by Nature and Reason, man can come to know his own best interests. A hugely popular book among rationalists and free thinkers of the late eighteenth and early nineteenth centuries, Volney's Ruins was still distressing to the Bridgehampton historian in 1910 who described Ruins in disgusted terms: "It was . . . expected to supplant the Scriptures and be recognized as an authority when the Bible should have been relegated to the realm of old wives fables." In light of Burroughs's other suggestions, it seems quite in character that he would have introduced Volney into the discussion but later excised the reference out of his memoirs. Whatever the truth, Burroughs was clearly thought capable of having ordered such a title, and that would itself label him as a dissenting voice in a rural township. See John E. Heartt, ed., The Story of a Celebration, Bridgehampton, Long Island 1660-1910 (Bridgehampton, N.Y.: Hampton Printing and Publishing Company, Press of the Bridgehampton News, 1910), 96. Volney's Ruins is not referred to in the other local histories I have consulted, most significantly, Ralph G. Duvall, The History of Shelter Island 1652-1932, with a Supplement 1932-1952 by Jean L. Schladermundt (Bridgehampton Heights, N.Y., 1952).

28. For insightful analysis of Burroughs and issues concerning identity surrounding criminal narratives of the early republic, see Daniel E. Williams, "In Defense of Self: Author and Authority in the Memoirs of Stephen Burroughs," Early American Literature 25, no. 2 (1990): 96-122. To more broadly situate Burroughs's narrative in the criminal narrative context, see Daniel E. Williams, ed., Pillars of Salt: An Anthology of Early American Criminal Narratives (New York: Madison House, 1993). Other good work on Burroughs and the problems of reading criminal narratives can be found in Kristen Boudreau, "Early American Criminal Narratives and the Problem of Public Sentiments," Early American Literature 32, no. 3 (1997): 249-69; Sean Michael Gallagher, "American Criminal Autobiography in the Nineteenth Century: 'Launched into Eternity," Ph.D. diss., University of Minnesota, 1994.

29. For an account of Burroughs's later career as a notorious counterfeiter in Canada, see the well-researched essay by Kenneth Scott, "Counterfeiting in Early Vermont," Vermont History 33, no. 2 (1965): 296-307.

30. As quoted by Aurelia Grether Scott, "The Strange Case of an Early Long Island Schoolmaster," Journal of Long Island History 7, no. 2 (1967): 20-21.

31. Gura, "Foreword," xvii.

32. The legacy of Burroughs's own memoirs as a medium for corruption was felt by later generations in Bridgehampton. One of Woolworth's eighteenth-century cronies, David Hedges, apparently passed his grudge against Burroughs along to his grandson, Judge Henry P. Hedges. Throughout his lifetime Judge Hedges reportedly would "confiscate and destroy every copy of "Burroughs's Memoirs' that he could obtain in any way, regardless of ownership." One of Hedges's contemporaries observed that this practice, "instead of blotting out the memory of this man, ... . served to perpetuate that memory above any other method he might have chosen." Moreover, since Judge Hedges later purchased the site upon which Burroughs and his family had lived during their stay in Bridgehampton, it is especially interesting to note that Judge Hedges compiled the extant library catalog of the original Burroughs library and publicized it by supplying it to local historians for reprinting. It seems quite possible that Hedges might have purged either the collection or altered the final book list to eliminate any record of the bad books Burroughs might have introduced into the library. 
William Donaldson Halsey, Sketches from Local History (Bridgehampton, N.Y., 1935), 36. I have not been able to obtain the actual manuscript of the original Burroughs catalog, nor have I located the copy Judge Hedges must have made of it in the nineteenth or early twentieth century. The list as discussed here and in the appendix is compiled from a version reprinted in Halsey, Sketches.

33. See Robert B. Winans, "The Growth of the Novel-Reading Public in LateEighteenth-Century America," Early American Literature 9 (1975): 267-75.

34. Robert B. Winans, "Bibliography and the Cultural Historian," in Joyce et al., eds., Printing and Society, 178. Cathy Davidson outlines the complex debates over novel reading in an accessible and efficient manner in chapter 3 of Revolution and the Word: The Rise of the Novel in America (New York: Oxford University Press, 1986).

35. Richard Beale Davis, A Colonial Southern Bookshelf: Reading in the Eighteenth Century (Athens: University of Georgia Press, 1979), 123.

36. See Boudreau, "Early American Criminal Narratives."

\section{Appendix}

Judge Henry P. Hedges, an amateur historian, assembled a list of books at some point during the late nineteenth century. He identified this list as comprising the original "Burroughs Library." The list was obtained and reprinted by James Truslow Adams in his Memorials of Old Bridgehampton (Bridgehampton, N.Y.: Privately printed, 1916). The titles in this list are often abbreviated beyond recognition, authors' names are not always included, and it is difficult to know which editions would have been purchased. Some of the titles seem chronologically suspect as well; they may be nineteenth-century books added to the library well after the initial collection was assembled. Furthermore, as discussed in my essay, Judge Hedges was hardly a reliable source. Historian William Donaldson Halsey in his Sketches from Local History mentions the rumor that as the son of one of Burroughs's original enemies, the judge reportedly destroyed every edition of Burroughs's Memoirs he could get his hands on and may well have filched or edited books out of the original collection list (see note 32). If Halsey's accusations have any merit, the judge is certainly a difficult source upon which to rely. Yet even with its problematic origins, the list is a remarkable document that attests to the accuracy of Burroughs's story as well as to the reading preferences of early Americans.

The bulk of the titles to which Burroughs refers in his account can be found in the collection: Gay's Fables, Bancroft's History of Charles Wentworth, Rollin's Ancient History, Plutarch's Lives, and, of course, Henry Brooke's Fool of Quality. Some of the books that Burroughs suggests, notably, the Voltaire and the Hume, did not make it onto this final list. Also absent was Volney's Ruins, which another Bridgehampton historian, John E. Heartt, in The Story of a Celebration, Bridgehampton, 
Long Island 1660-1910 (Bridgehampton, N.Y.: Hampton Printing and Publishing Company, Press of the Bridgehampton News, 1910), cited as the source of the entire library dispute, even though Burroughs's own account makes no reference to it whatsoever.

The remaining collection is, nonetheless, quite varied. Fiction is well represented, and the four volumes of Arabian Nights' Entertainment seem to have raised few eyebrows. A handful of novels, such as Samuel Richardson's Clarissa Harlowe, appears, and the satirical poems by Peter Pindar (John Wolcot) are also listed. Some poetry is certainly contained in the various miscellanies such as the Beauties of the Magazine. And Milton's Paradise Lost-ever a popular text in early America-suggests also an interest in longer poetic and literary works.

Bridgehampton was well populated with whalers, fishermen, and sailors. It is not surprising, therefore, that so many works of travel are included on the list: Moore's France and Italy, Cook's Travels, Bruce's Travels up the Nile, and Sparman's Voyage to the Cape of Good Hope. Whether these were solely purchased for reasons of intellectual curiosity or practical application it is impossible to determine, but pragmatic interests are indicated by the inclusion of texts such as Mills's Cattle, Perry's Pronouncing Dictionary, the Compleat Letter Writer, and Guthrie's Geographies.

While there are certainly a number of religious texts on this list, they tend to have an accessible and less arcane bent than most. In addition to texts such as Linn's Characteristical Sermons, Watts's Foundations of the Christian Church, and Doddridge's Rise and Progress of Religion, there are sermons specifically for young men and women as well as epistolary advice manuals such as Miss Rowe's Letters.

Although Thomas Paine was certainly popular reading in eighteenth-century America, his inclusion in the library is notable as part of the specifically American focus of this collection. Other particularly American interests are indicated by the inclusion of Barlow's Visions of Columbus, Carver's Travels (an account of explorations in North America), and even Emma Corbett (a popular romance by British author Samuel Jackson Pratt set during the American Revolution). Minister Woolworth's favorite author, Jonathan Edwards, is well represented, and the inclusion of Franklin's Life-a text that has extensive and provocative parallels to Burroughs's own Memoirs-is a notable addition to this truly American collection.

In return for the pleasure and privilege of reading the books, a Bridgehampton villager by the name of Levi Hildreth agreed to house the library. The collection was used for many years until the books were so reduced in number that the library essentially ceased to exist. Although there was a small circulating library operating from 
1850 to 1870 or so, it wasn't until 1877 that a modern public library was opened in Bridgehampton.

\section{The Burroughs Library}

Here is the list of books Judge Hedges identified as comprising the original "Burroughs Library." It is presented in the order listed, precisely as originally cataloged. The four titles preceded by an asterisk have at least one volume still present in the Bridgehampton Library collection today. As they date from 1791 or earlier, it seems highly likely that these were the actual volumes ordered as part of the "Burroughs Library."

Raynal's Indies, 8 vols.

Rollins's Ancient History, 8 vols.

Hist. Of Modern Europe, 5 vols.

Moore's France, 2 vols.

Moore's Italy, 2 vols.

Robertson's America, 3 vols.

Robertson's Scotland, 2 vols.

Mirabeau's Court of Berlin, 2 vols.

Memoirs of Baron de Tott, 2 vols.

Fordyce's Addresses

Fordyce's Sermons to Young Women

Newton on the Prophecies, 3 vols.

Edwards on the Will

Death of Abel

Doddridge's Rise and Progress of Religion

Watts' Foundations of the Christian Church

Manners in Portugal, 2 vols.

Plutarch's Lives, 6 vols.

Arabian Nights' Entertainment, 4 vols.

Neal's Hist. Of the Puritans, 4 vols.

Ramsey's Revolution, 2 vols.

*Linn's Characteristical Sermons

Morse's Geography

Thomson's Seasons

Clerk's Vade Mecum

Pope's Essay on Man

Milton's Paradise Lost

Conquest of Canaan

Emma Corbett

Beauties of the Magazine 
Derham's Astro Theology

Paine's Rights of Man, 1st \& 2nd parts, 2 vols.

Montague's Letters, 3 vols.

Telemachus, 2 vols.

Compleat Letter Writer

Jennen's View

Jennen's Lectures

Beauties of History, 2 vols.

Knox on Education, 2 vols.

Miss Rowe's Letters

Bennett's Letter to a Lady

Memoirs of Baron Trenck

Visions of Columbus

Young's Night Thoughts

Humphrey's Works

Kaim's Art of Thinking

Sparman's Voyage to the Cape of Good Hope, 2 vols.

*Guthrie's Geography

Brisson's Narrative

Mosheim's Ecclesiastical History

*Flavius Josephus, 6 vols.

Perry's Pronouncing Dictionary

Clarke's Farriery

Hervey's Meditations

Burke on the French Revolution

Watt's Logick

Gustavus Vasa

Watt's Supplement

Edwards on Original Sin

Lathrop on Baptism

Life of Charles Wentworth, 3 vols.

Hervey's Letters, 2 vols.

Cook's Travels, 2 vols.

Edwards' Hist. Of Redemption

Goldsmith's Rome, 2 vols.

Wait's Gospel History

Hist. Of Charles XII of Sweden

Evans on the Christian Temper

Dickinson's Letters

Weft and Lyttleton

William's Sermons, 4 vols.

*Peter Pindar, 2 vols.

Adam's View of Religion 
Dodd on Death

Franklin's Life

England, Abridged

Cowper's Task

Carver's Travels

Blair's Sermons, 2 vols.

Lavater's Aphorisms on Man

Moore's Monitor

Gay's Fables

Paley's Philosophy

Byron's Shipwreck

Clarissa Harlowe, 3 vols.

British Moralist, 2 vols.

Bruce's Travels up the Nile

Warville's Travels

Cook's Voyages Abridged

Goldsmith's Animated Nature, 4 vols.

French Revolution

Mills on Cattle

Mason on Self Knowledge

Watts' Miscellaneous Thoughts

Fool of Quality, 5 vols. 